Nat. Hazards Earth Syst. Sci., 18, 3153-3166, 2018

https://doi.org/10.5194/nhess-18-3153-2018

(C) Author(s) 2018. This work is distributed under

the Creative Commons Attribution 4.0 License.

\title{
Impact of wildfires on Canada's oil sands facilities
}

\author{
Nima Khakzad \\ Faculty of Technology, Policy, and Management, Delft University of Technology, Delft 2628BX, the Netherlands
}

Correspondence: Nima Khakzad (n.khakzadrostami@tudelft.nl)

Received: 17 May 2018 - Discussion started: 6 July 2018

Accepted: 10 November 2018 - Published: 23 November 2018

\begin{abstract}
Exponential growth of oil and gas facilities in wildlands from one side and an anticipated increase of global warming from the other have exposed such facilities to an ever-increasing risk of wildfires. Extensive oil sands operations in Canadian wildlands, especially in the province of Alberta, along with the recent massive wildfires in the province, require the development of quantitative risk assessment (QRA) methodologies which are presently lacking in the context of wildfire-related technological accidents. The present study is an attempt to integrate Canadian online wildfire information systems with current QRA techniques in a dynamic risk assessment framework for wildfire-prone process plants. The developed framework can easily be customized to other process plants potentially exposed to wildfires worldwide, provided that the required wildfire information is available.
\end{abstract}

\section{Introduction}

Rising temperatures and climate change have increased the risk of weather-related hazards in Europe (European Joint Research Centre, 2017). Canada and the US are no exception as evident by the recent hurricanes, floods, and wildfires which devastated the states of Texas and California in the US and the provinces of British Columbia and Alberta in Canada. Aside from the impact of such natural disasters on the environment and urban areas, their effect on industrial plants and hazardous facilities (process plants, nuclear plants, etc.) has started to raise concerns in academia, the industry, and regulatory bodies.

Massive fires in a refinery in Turkey in 1999 during the Kocaeli earthquake, substantial release of petroleum products and chemicals in the US during Hurricane Katrina in 2005 and Hurricane Harvey in 2017, extensive damage to coastal industrial complexes in Japan in 2011 during the Great Sendai Earthquake and the following tsunami, and shutdown of oil sands plants which incurred enormous oil production losses during massive wildfires in Canada in 2016 are just some examples among others.

Although the hazard of wildfires in ecological and urban risk assessment studies has long been recognized (Preisler et al., 2004; Scott et al., 2012, 2013;), the relevant work in the context of wildland-prone industrial complexes has been very limited (FireSmart, 2012; Khakzad et al., 2018). In Europe, for example, Seveso Directive III (2012) has only recently mandated the member states to consider the probability of natural disasters in the risk assessment of major accident scenarios when preparing safety reports (Article 10), with an explicit mention of floods and earthquakes (the Annex II) but not of wildfires. Most European countries that consider natechs (natural hazards triggering technological disasters) have likewise limited their focus to only a few natural hazards (Krausmann and Baranzini, 2012). Table 1 exemplifies some of such efforts.

Exponential growth of industrial facilities and the subsequent prolongation of wildland-industry interfaces from one side and an anticipated increase of global warming from the other are expected to increase the frequency and severity of technological accidents caused by natural disasters, including wildfires.

In May 2015, a massive wildfire in northern Alberta, Canada, spread into the oil sands areas, threatening several operations and keeping about $10 \%$ of the production offline. Two major petroleum companies, Canadian Natural and Cenovus Energy, shut down their 80000 and 135000 -barrel-aday operations, respectively, for safety precautions as the fires approached Foster Creek oil sands facility and Caribou South natural gas plant (Mining.Com, 2015). 
Table 1. Natural hazards considered in safety assessment and management of process plants in the European Union (Krausmann and Baranzini, 2012).

\begin{tabular}{ll}
\hline Country & Natural hazard \\
\hline Lithuania & Floods \\
Slovakia & Floods \\
Czech Republic & Mainly floods \\
UK & Mainly floods \\
Romania & Floods, landslides, earthquakes \\
Germany & Floods, storms, earthquakes \\
France & Floods, landslides, earthquakes, lightning \\
Italy & Floods, storms, earthquakes, lightning, wildfire \\
Netherlands & All-hazards approach* \\
\hline
\end{tabular}

* It is not identified whether it accounts for wildfires.

In May 2016, a wildfire burned part of Fort McMurray, Alberta, Canada, and spread towards oil sands plants north of the city where major oil sands production plants Syncrude and Suncor Energy along with some smaller petroleum operations were located, resulting in a $40 \%$ drop in production at nearby oil sands facilities (Fig. 1).

The operations shutdowns or reductions were also influenced by precautionary shutdowns of pipeline carrying diluent, a flammable substance needed to thin the oil sands' bitumen, resulting in a reduction of the oil sands' output of roughly as much as 1 million barrels a day (Maclean's, 2016a). The wildfire did not cause damage to oil sands plants and process equipment, but it burned down a 665-unit worker accommodation camp in northern Fort McMurray (Global News, 2016a). But what would have happened if the fire had reached the oil sands mines and the production facilities?

As far as the oil sands mines are concerned, bitumen, the main component of oil sands, does not easily catch fire (Global News, 2016b). Considering the fact that $80 \%$ of bitumen is buried deep underground, the bitumen in oil sands mines is mixed with sand (similar to asphalt), and would probably smolder if ignited (Maclean's, 2016b). However, oil sands projects rely on two highly flammable substances for the extraction, processing and transport of bitumen: natural gas and diluent, which is a very light petroleum substance.

Natural gas is used to generate power for the plants and heat up the steam used to liquefy the bitumen. Diluent, on the other hand, is used to dilute the crude bitumen thin enough to flow through pipelines. Both the natural gas and diluent can pose high risks if exposed to fire, though the pipes carrying them are usually buried underground.

Oil sands process plants are usually accompanied by large tank terminals in the vicinity to store oil products. Exposed to external fires (such as wildfire), buckling of atmospheric storage tanks and spill of hydrocarbons, tank fires, vapor cloud explosions, and explosion of pressurized tanks can be recognized as potential risks (Heymes et al., 2013, Godoy 2016). In case one or more storage tanks are ignited by the wildfire,

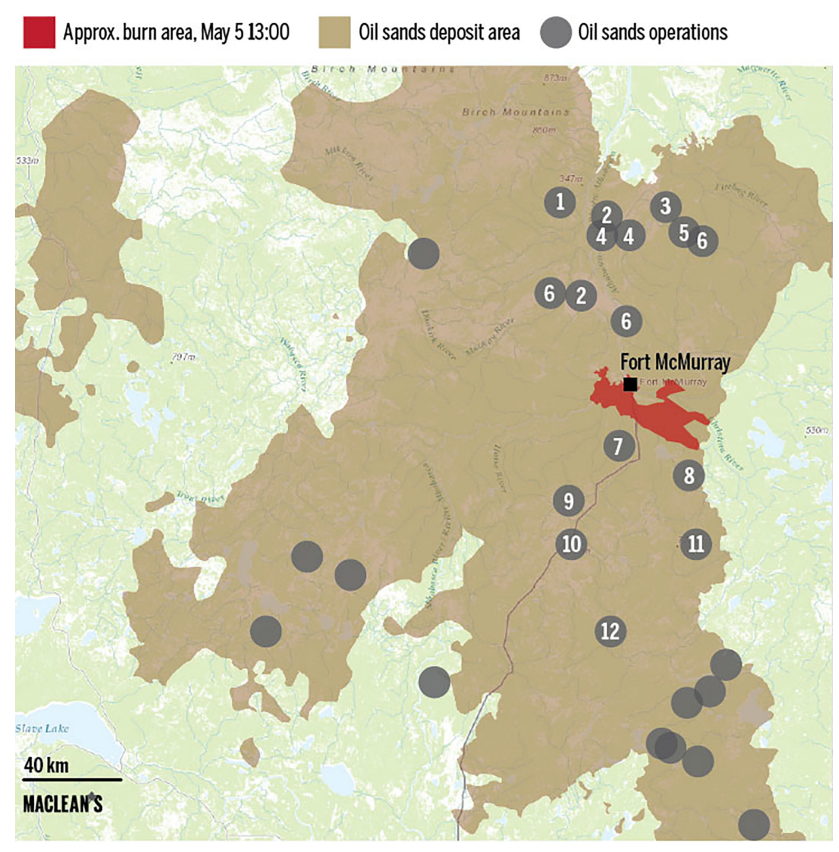

Figure 1. Wildfire in Fort McMurray and the location of affected oil sands plants: 1 Canadian Natural Resources, 2 Syncrude joint venture, 3 Imperial Oil, 4 Shell Canada, 5 Husky Energy/BP, 6 Suncor, 7 Athabasca, 8 Nexen (CNOOC), 9 Japan Canada Oil Sands, 10 Connacher Oil and Gas, 11 ConocoPhillips, 12 Statoil (Maclean's, 2016a).

the tank fire(s) can impact adjacent storage tanks, leading to a fire domino effect.

In order to protect oil sands facilities from wildfires (and also protect the forest from potential ignition sources at the facilities), there is a buffer zone (safety distance in the form of vegetation-free ground) between facilities and forest vegetation. In the absence of methodologies for quantitative risk assessment and management in wildland-industrial interfaces, such buffer zones are usually determined based on rule-of-thumb guidelines (e.g., see FireSmart, 2012). Numerical simulations of storage tanks exposed to wildfire have, however, demonstrated that in most cases such safety distances would not suffice (Heymes et al., 2013).

Due to extensive oil sands operations in Canadian wildlands, in the present study, we have developed a dynamic framework, mainly based on available techniques and daily updated wildfire maps made available online by the government of Canada, to assess the impact of wildfires on oil sands facilities. Since the framework is modular, it can be tailored to assess the risk of wildfires at process plants in wildfireprone areas worldwide. Section 2 revisits the Canadian wildland fire information system; in Sect. 3, the components of wildfire risk assessment are described and quantified; Sect. 4 is devoted to the impact assessment of wildfires on process facilities; Sect. 5 concludes the study. 


\section{Canadian Wildfire Information System}

In Canada, two systems are being used to determine the characteristics and the hazard of wildfires: the Canadian Forest Fire Weather Index (FWI) System and the Canadian Forest Fire Behavior Prediction (FBP) System. The former is mostly concerned with the estimation of wildfires' basic components (e.g., flammability of vegetation), whereas the latter deals with the dynamics of wildfires (e.g., fire intensity). Since in the present study the identification and quantification of wildfires in Canadian wildlands are mainly based on the foregoing two systems, they will be recapitulated in this section.

\subsection{Forest Fire Weather Index System}

Wildfires, like other types of fire, can be defined using the fire triangle consisting of fuel (trees, grasses, shrubs), oxygen, and heat source. As far as the fuel is concerned, parameters such as the Fine Fuel Moisture Code (FFMC), which is the moisture content of litter and other crude fire fuels, Duff Moisture Code (DMC), which is the moisture content of loosely compacted organic layers of moderate depth and woody materials, and Drought Code (DC), which is the average moisture content of deep compact organic layers and large logs, are taken into account to determine both the ease of ignition and the flammability of the available fuel.

DMC and DC are combined together to determine the total amount of combustible materials in the form of a so-called Buildup Index (BUI). Accordingly, the wind and the FFMC are combined to predict the rate of fire spread in the form of a so-called Initial Spread Index (ISI). Having the BUI and the ISI, the FWI, as an indication of fire danger, can be determined as shown in Fig. 2 (Natural Resources Canada, 2018).

Figure 3a illustrates the FWI of Canada $(0 \leq \mathrm{FWI} \leq 30)$ on 1 May 2016, a day before the Fort McMurray wildfire. Based on the FWI and the type of fire (surface fire, crown fire, intermittent crown involvement), the fire danger index can be determined (low, moderate, high, very high, extreme) as an indication of how easy it is to ignite the forest fuel, how difficult it is to control the fire, and the type of firefighting equipment needed (pumps, tanker trucks, bulldozer, aircraft, etc.) as shown in Fig. 3b.

\subsection{Forest Fire Behavior Prediction System}

To quantify the impact of wildfires on industrial plants, quantitative estimates of head fire spread rate, fuel consumption and fire intensity are needed. The FBP System employs PROMTHEUS - a deterministic wildland fire growth simulation model based on Huygens' principle of wave propagation - to estimate the fire area, perimeter, perimeter growth rate, and flank and back fire behavior (Tymstra et al., 2010). The rate of spread (ROS) is the predicted speed $\left(\mathrm{m} \mathrm{min}^{-1}\right)$ of the fire head (fire front), which is calculated based on the fuel

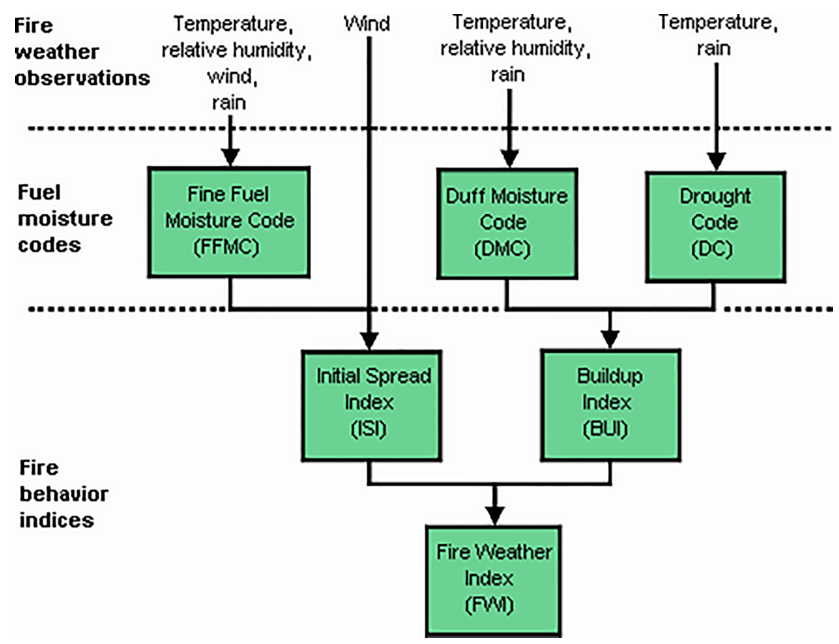

Figure 2. Identification of the Fire Weather Index (Natural Resources Canada).

type, ISI, BUI, crown base height and other parameters based on the FWI and FBP subsystems of the Canadian Forest Fire Danger Rating System.

Head fire intensity (HFI) is an estimate of the energy output per meter of the fire front $\left(\mathrm{kW} \mathrm{m}^{-1}\right)$, calculated based on the ROS and total fuel consumption $\left(\mathrm{kg} \mathrm{m}^{-2}\right)$. The ROS and HFI indices calculated by the Canadian Wildland Fire Information System a day before the start of the Fort McMurray wildfire are shown in Fig. 4a and b, respectively (Natural Resources Canada).

\section{Wildfire risk assessment}

In wildfire risk assessment, the ignition probability, burn probability (the probability that wildfire reaches to a certain spot), type of fire (surface fire, crown fire, intermittent crown involvement) and fire intensity are the main factors to take into account (Scott et al., 2013).

Many methodologies have been developed to predict the lightning-induced ignition probability (Latham and Schlieter, 1989; Anderson, 2002) and human-induced ignition probability (Lawson et al., 1994) to model surface fire spread (Rothermel, 1972), crown fire spread (Rothermel, 1991), and the transition between surface and crown fire spread (van Wagner, 1977). Accordingly, a number of software tools such as FARSITE (Finney, 1998), FlamMap5 (Finney, 2006), FSPro (Finney et al., 2011a) and FSim (Finney et al., 2011b) have been developed based on historical records of regional wildfires, weather conditions, type and density of vegetation in the landscape, and the topology of the landscape. Using the developed models and software tools, the risk imposed by wildfires on an oil sands facility can be modeled as the 

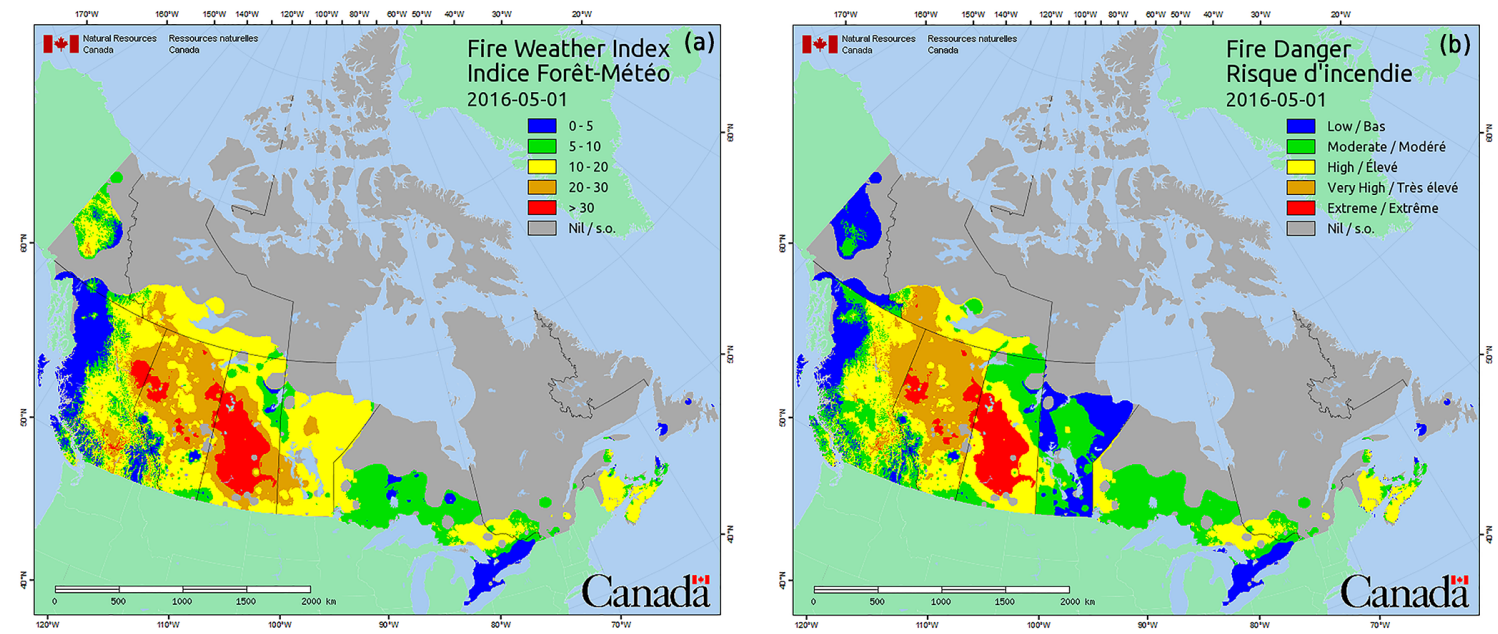

Figure 3. (a) Fire Weather Index and (b) fire danger index of Canada on 1 May 2016 (Natural Resources Canada).
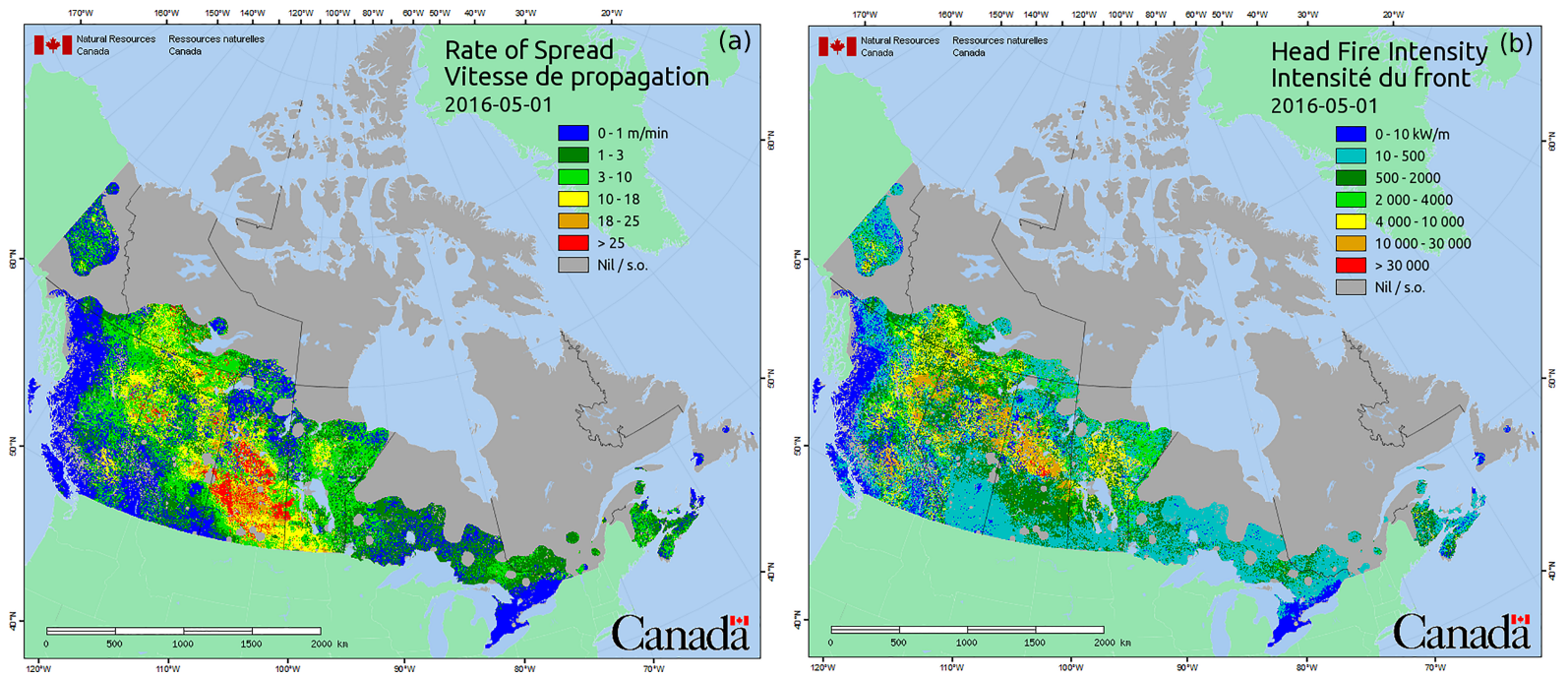

Figure 4. (a) Fire rate of spread and (b) head fire intensity in Canada on 1 May 2016 (Natural Resources Canada).

product of the wildfire probability, $P_{\mathrm{W}}$, and the severity of consequences, preferably in monetary units as

wildfires' risk $=P_{\mathrm{W}} \cdot$ consequence.

Given the geographical location of the facility, the probability of wildfire at the borders of the facility can be estimated as the probability of having a small fire somewhere at the landscape $\left(P_{\mathrm{I}}\right)$ times the probability of the small fire growing to a wildfire larger than $400 \mathrm{~m}^{2}$ in area and reaching the location of the facility $\left(P_{\mathrm{B}}\right)$ :

$P_{\mathrm{W}}=P_{\mathrm{I}} \cdot P_{\mathrm{B}}$.

$P_{\mathrm{I}}$ and $P_{\mathrm{B}}$ are also known as ignition probability and burn probability, respectively. Exposed to a wildfire, the potential consequences and their severity depend on the wildfire intensity and the facility's vulnerability to wildfire: $C=f$ (fire intensity, facility's vulnerability) ${ }^{1}$. In the following sections we will describe the components of wildfire risk in further detail and explain how they can be estimated or acquired from available (mostly freely accessible) models and databases, with a particular emphasis on the Canadian Forest Fire System.

\subsection{Ignition probability}

Wildfires can be categorized as hydrogeological events which are bound to increase, especially due to global warm-

\footnotetext{
${ }^{1}$ In the present study, we do not consider the indirect risk incurred by, among others, loss of production due to the plant's precautionary shutdowns, staff evacuation, or the like.
} 
ing. Every degree in warming increases the possibility of lightning, which is one of the major triggers of wildfires, by $12 \%$ (Romps et al., 2014). Likewise, $15 \%$ more precipitation would be needed to offset the increased risk of wildfires due to a $1^{\circ} \mathrm{C}$ increment of warming (Flannigan et al., 2016). Nevertheless, man-made fires (burning campfires, cigarettes) account for $80 \%$ of wildfires (National Geographic, 2018.).

Weather conditions such as temperature, relative humidity, and wind speed are key factors in the probability estimation of an ignition (small fire) which can lead to a wildfire. In addition to the weather conditions, the vegetation moisture content (equal to FFMC) plays a key role, not only in the initiation of fire (the ignition probability) but also in the continuation and spread of fire (fuel flammability) (Chuvieco et al., 2004).

Based on the measurement of FFMC in consecutive time periods before the start of a potential wildfire, the logistic regression has been used to roughly predict $P_{\mathrm{I}}$ based on FFMC (Larjavaara et al., 2004; Jurdao et al., 2012). Similarly, Preisler et al. (2004) used the logistic regression to predict the probability of small fires (fires in areas less than 0.04 ha) as an equivalent to $P_{\mathrm{I}}$ based on, among others, the burning index, fire potential index, Drought Code, wind speed, relative humidity, dry bulb temperature, day of the year, and the elevation.

Lawson et al. (1994) developed an application called the Wildfire Ignition Probability Predictor (WIPP) to predict, on an hourly or daily basis, the $P_{\mathrm{I}}$ of man-made wildfires in British Columbia forests, Canada. Based on the calculations of FFMC and $10 \mathrm{~m}$ wind speed, WIPP estimates the $P_{\mathrm{I}}$ in three categories as low $(0 \%-50 \%)$, medium $(50 \%-75 \%)$, and high (75\%-100\%). Considering lightning as one of the main triggers of wildfires, Canadian Wildland Fire System estimates the time-dependent probability of lightning-caused ignitions as (Anderson, 2002):

$P_{\mathrm{I}}=P_{\mathrm{LCC}} \cdot P_{\text {ign }} \cdot P_{\text {sur }} \cdot P_{\text {arr }}$,

where $P_{\mathrm{LCC}}$ is the probability of a long-continuing current ( $85 \%$ for positive flashes, $20 \%$ for negative flashes across Canada); $P_{\text {ign }}$ is the probability of ignition given a longcontinuing current, determined by fuel type, forest floor depth, and moisture conditions (Latham and Schlieter 1989; Anderson 2002); $P_{\text {sur }}$ is the probability that a smoldering ignition will continue to survive as a smoldering fire, determined by the fuel moisture, the bulk density, and the inorganic content of the forest floor (Hartford 1989; Anderson 2002); $P_{\text {arr }}$ is the probability of a smoldering fire escalating to a flaming fire (Lawson et al., 1994; Forestry Canada Fire Danger Working Group, 1992; Anderson, 2002).

Wildfire-prone provinces in Canada such as Alberta and British Columbia provide ignition probability maps on a daily basis both for the current day and the next day. Figure 5 depicts the $P_{\mathrm{I}}$ map for the province of Alberta administrated by Alberta Agriculture and Forestry.

\section{Alberta}

Wildfire Ignition Probability for October 17, 2017
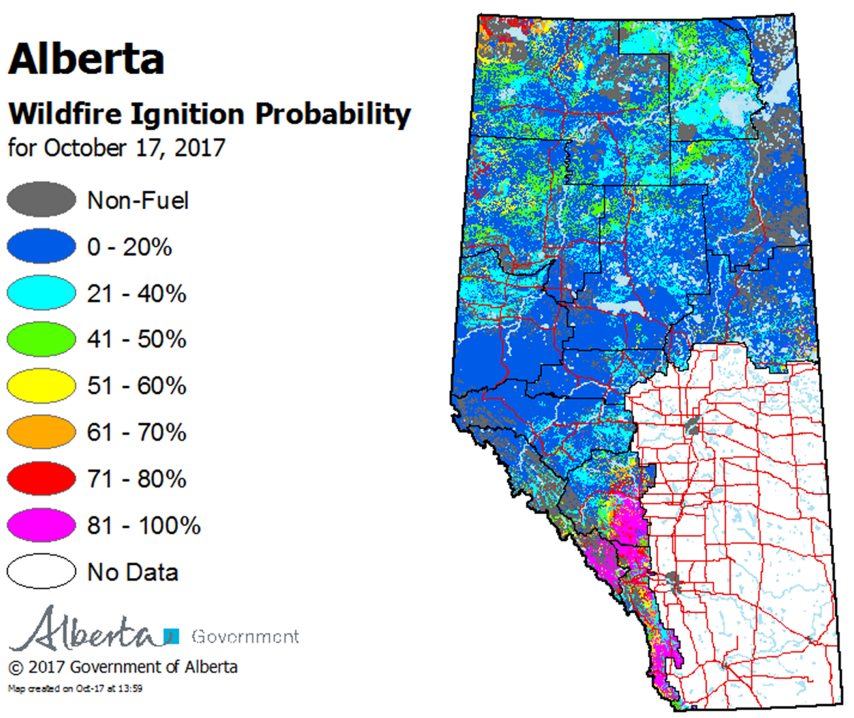

Figure 5. Wildfire ignition probability $\left(P_{\mathrm{I}}\right)$ in Alberta, Canada (http://wildfire.alberta.ca, last access: 17 October 2017).

\subsection{Burn probability}

Burn probability $\left(P_{\mathrm{B}}\right)$ is the conditional probability that a small fire somewhere in the landscape would escalate to a wildfire and burn somewhere else in the landscape. Estimation of $P_{\mathrm{B}}$ is challenging as the spread of wildfire from one point to another is a complicated process affected by many factors such as the type of vegetation (fuel), weather conditions, and land topology. These factors, in turn, consist of several key parameters such as the flammability of fuel, vertical arrangement of fuel, moisture content of fuel, wind speed and direction, relative humidity, the orientation of fire (downhill or uphill) and the type of fire (surface fire, crown fire, surface-crown transition).

Considering the foregoing fire spread parameters, $P_{\mathrm{B}}$ can be estimated as the relative frequency of wildfires' burning a certain spot, given a number of small fires at different spots of the landscape (Scott et al., 2013). Models developed for wildfire spread simulation include empirical, semiempirical, and physical models (Pastor et al., 2003). Some of these models such as FARSITE ${ }^{2}$ (Finney, 1998) and BehavePlus (Andrews, 2013) need detailed spatial information on topography, fuels, and weather conditions, not readily available for many locations of interest. A comprehensive review of wildfire simulation models can be found in Papadopoulos and Pavlidou (2011). Less sophisticated models and software have also been developed for fire spread modeling and investigation of whether a small fire at point A would evolve as a wildfire at point $\mathrm{B}$ in the landscape.

To estimate $P_{\mathrm{B}}$, fire spread models should simulate thousands of wildfires from various ignition points (Finney,

\footnotetext{
${ }^{2}$ FARSITE is available from https://www.firelab.org/project/ farsite (last access: 20 September 2018).
} 


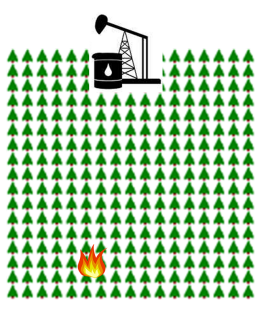

(a)

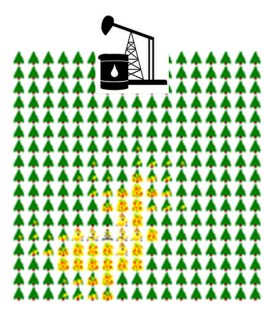

(b)

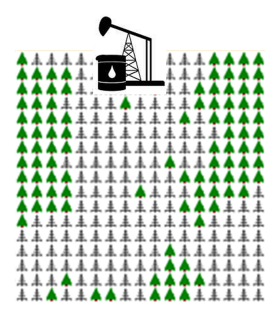

(c)
Figure 6. Wildfire spread in a hypothetical landscape. (a) Random ignition of a small fire in the landscape. (b) The small fire escalates as a wildfire. (c) The wildfire reaches an oil facility.

2002). For instance, Fig. 6 schematizes a fire spread model ${ }^{3}$ in which a random small fire (ignition) somewhere in the landscape (Fig. 6a) evolves to a wildfire (Fig. 6b) and reaches an oil sands plant (Fig. 6c). The probability of the wildfire reaching the oil facility can thus roughly be estimated as

$P_{\mathrm{B}}=\frac{n}{N}$,

where $N$ is the total number of simulations, that is, the total number of random small fires at different spots of the landscape; and $n$ is the total number of simulations in which a small fire turned out as a wildfire and reached the facility.

Similar attempts have been made, for example, using NetLogo (Wilensky, 1997), which is a multi-agent programmable modeling environment, to model fire spread though it is based on simplistic assumptions and uses tree density as the only parameter.

\subsection{Fire intensity}

Head fire intensity (HFI) is the rate of heat release per unit length of the fire head $\left(\mathrm{kW} \mathrm{m}^{-1}\right)$, regardless of the fire's depth. HFI, which is also known as Byram's fire intensity or frontal fire intensity, can be calculated as (Byram, 1959)

$\mathrm{HFI}=H \cdot w \cdot r$,

where $H\left(\mathrm{~kJ} \mathrm{~kg}^{-1}\right)$ is the fuel's low heat of combustion, $w$ $\left(\mathrm{kg} \mathrm{m}^{-2}\right)$ is the fuel's combustion rate in the flaming zone, and $r\left(\mathrm{~m} \mathrm{~s}^{-1}\right)$ is the fire's spread rate in the direction of the fire head (Fig. 7). $H$ is equal to the high heat of combustion minus the heat losses from radiation, incomplete combustion, and fuel moisture. Compared to the other parameters in Byram's fire intensity, $H$ varies slightly from fuel to fuel and can thus be considered as a constant. Alexander (1982) suggests a basic value of $18700 \mathrm{~kJ} \mathrm{~kg}^{-1}$.

Values of $r$ and $w$, however, can vary significantly for different fuels. Considering $r$, for instance, a grass fire may travel at a rate of $r=5 \mathrm{~km} \mathrm{~h}^{-1}$, whereas fire in a dry eucalypti forest may travel at a rate of $r=1 \mathrm{~km} \mathrm{~h}^{-1}$ capable

\footnotetext{
${ }^{3}$ The program is available from http://www.shodor.org/ interactivate/activities/Fire/ (last access: 20 September 2018).
}

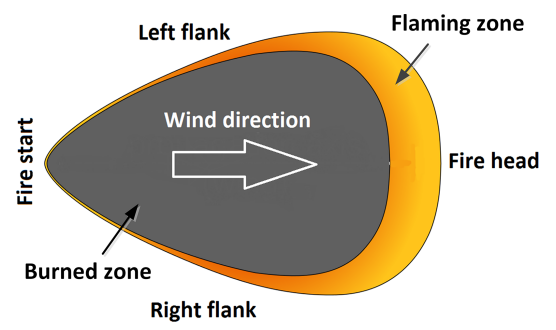

Figure 7. Different zones of a wildfire (adapted from Wikipedia).

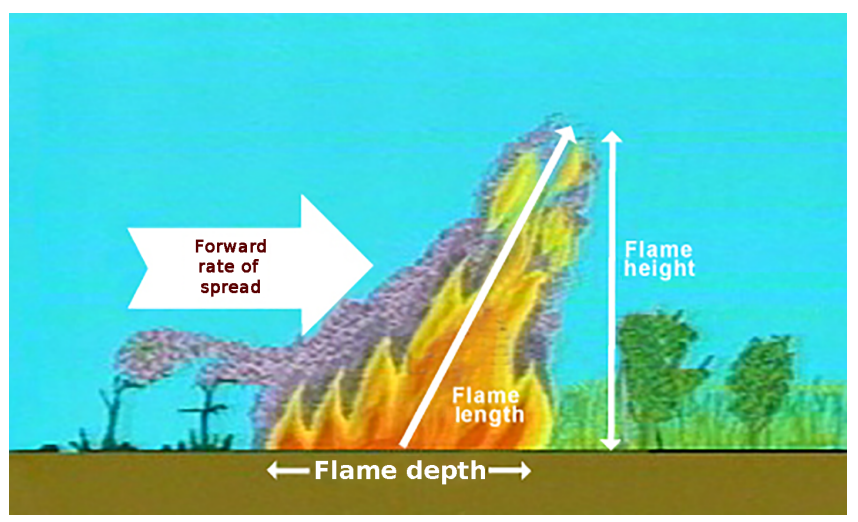

Figure 8. Flame characteristics.

of throwing embers up to $1 \mathrm{~km}$ ahead of the fire (Cheney, 1990; Cheney et al., 1998). As a result, HFI can vary from 15 to $100000 \mathrm{~kW} \mathrm{~m}^{-1}$ (Byram, 1959), though it rarely exceeds $50000 \mathrm{~kW} \mathrm{~m}^{-1}$, and for most crown fires lies in the range of $10000-30000 \mathrm{~kW} \mathrm{~m}^{-1}$ (Alexander, 1982). Having the flame length, $L(\mathrm{~m})$, Byram (1959) has suggested Eq. (6) to calculate the HFI of surface fires:

$\mathrm{HFI}=260 L^{2.174}$.

In case of crown fires, one-half of the mean canopy height should be added to $L$ (Byram, 1959). Flame length $(L)$, flame height $(h)$, and the flame depth $(D)$ have been depicted in Fig. 8. At very low wind speeds on level terrain, $h$ and $L$ can be considered to be the same. A thorough review of developed relationships to calculate the fire intensity based on the fire length can be found in Alexander and Cruz (2012).

Based on the flame length $(L)$, the fire intensity (HFI) can also be classified into six classes (Scott et al., 2013) as listed in Table 2; this way, the observations of $L$ can be used to make rough estimates of HFI.

The fire intensity classes in Table 2 can be associated with the wildfire ranks used by the British Columbia Wildfire Service $^{4}$ for a quick description of fire behavior based on wildfire visual observations (Table 3). Similar classes to those in

\footnotetext{
${ }^{4}$ https://www2.gov.bc.ca/gov/content/safety/wildfire-status/ about-bcws/wildfire-response/fire-characteristics/rank (last access: 20 September 2018).
} 
Table 2. Flame length range associated with six standard fire intensity classes.

\begin{tabular}{ll}
\hline Fire intensity class & Flame length $(\mathrm{m})$ \\
\hline Class 1 & $0.0-0.6$ \\
Class 2 & $0.6-1.2$ \\
Class 3 & $1.2-1.8$ \\
Class 4 & $1.8-2.4$ \\
Class 5 & $2.4-3.7$ \\
Class 6a & $3.7-15$ \\
Class 6b & $>15$ \\
\hline
\end{tabular}

Tables 2 and 3 are also provided by Canadian wildfire protection agencies such as Alberta Wildfire (Fig. 9), which accordingly can be used to infer the flame length $(L)$ using Table 2 and then to estimate the fire intensity (HFI) using Eq. (6). As another option, the head fire intensity maps provided by the Canadian Wildfire System (Fig. 4b) can be used to directly identify the HFI.

Having the flame depth $(D)$, the frontal fire intensity (HFI) can be converted to area-fire or reaction intensity $Q$ $\left(\mathrm{kW} \mathrm{m}^{-2}\right)$ (Alexander, 1982):

$Q=\frac{\mathrm{HFI}}{D}$.

Considering the flame as a solid body (Butler and Cohen, 2000; Heymes et al., 2013), the amount of reaction intensity at a distance of $x$ from the flame's ground center (see Appendix B) can be calculated using the Solid Flame Model (Mudan, 1987) as

$Q_{x}=Q \cdot F_{\text {view }} \cdot \tau_{\mathrm{a}}$,

where $F_{\text {view }}$, the view factor, is the fraction of the heat radiation received by a receptor (Assael and Kakosimos, 2010), and $\tau_{\mathrm{a}} \in[0,1]$ is the atmospheric transmissivity, corresponding to the fraction of the thermal radiation received by the receptor considering the mitigation effect of humidity and carbon dioxide as well as the dissipation due to the distance. In the determination of safety zones, $\tau_{\mathrm{a}}=1$ is used for conservative results (Heymes et al., 2013).

\section{Impact of wildfire on oil storage tanks}

During wildfires, the main threats to oil sands facilities - either the process plant or the storage terminal - come from airborne embers and radiant heat. The threat of airborne embers is even greater since they are able to travel with wind for several kilometers ahead of the fire front. The accumulation of airborne embers near tank openings and vents or under the base of structures and process vessels, given enough vegetation or spilled flammable hydrocarbons, can ignite a fire also known as spotting (FireSmart, 2012) - which may easily

\section{Alberta}
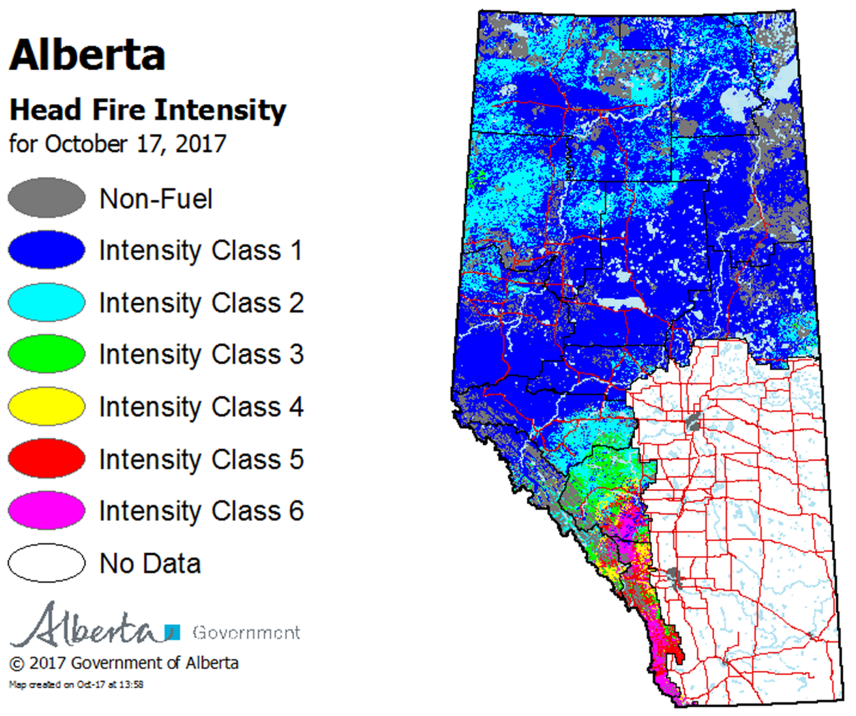

Figure 9. Wildfire intensity classes in Alberta, Canada (http:// wildfire.alberta.ca, last access: 17 October 2017).

escalate to a major fire and possibly a domino effect given the large inventory of flammable substances stored in the facility.

Assessing the risk of wildfires' embers is very tricky considering several influential parameters such as the direction and speed of the wind, the trajectory of embers, the accumulation of embers near critical spots, availability of on-site vegetation or spilled hydrocarbons, whose prediction is subject to large uncertainties if not impossible. Despite the difficulties in impact assessment of wildfire embers, simple protection and mitigation measures can be taken to effectively reduce their threat. For instance, limiting the use of floating roof tanks as the most common type of tanks reportedly involved in tank fires (Godoy, 2016), encouraging the use of cone roof tanks to prevent embers from landing around openings and vents, turning the vents downward and covering the openings with wire mesh, removing vegetation around tanks and combustible structures and equipping the structures and storage tanks with sprinkler systems are some of the measures to tackle the risk of airborne embers (FireSmart, 2012).

Aside from the impact of embers, the radiant heat emitted from the wildfire can threat the integrity and safety of process vessels and storage tanks. The type and severity of such an impact depends on the intensity of the radiant heat received by target vessels as well as their type (atmospheric, pressurized, pipeline, etc.) and dimension (usually their volume). Radiant heat acts as a thermal load on the wall of the vessels, which are categorized as thin-walled structures, and affects the stiffness and strength properties of the wall material (usually steel in the oil and gas industry).

In the case of atmospheric storage tanks such as oil and gasoline tanks, this change in properties results in wall weakening and is usually followed by large radial displacements in the form of buckling (Godoy, 2016). Buckling of steel stor- 
Table 3. Wildfire ranks used by the British Columbia Wildfire Service to determine the fire intensity.

\begin{tabular}{|c|c|c|c|}
\hline Visualization & Rank & Description & Characteristics \\
\hline & 1 & Smouldering ground fire & $\begin{array}{l}\text { - Smouldering ground fire } \\
\text { - No open flame } \\
\text { - White smoke } \\
\text { - Slow (i.e., creeping) rate of fire spread }\end{array}$ \\
\hline & 2 & Low vigor surface fire & $\begin{array}{l}\text { - Surface fire } \\
\text { - Visible, open flame } \\
\text { - Unorganized or inconsistent flame front } \\
\text { - Slow rate of spread }\end{array}$ \\
\hline & 3 & Moderately vigorous surface fire & $\begin{array}{l}\text { - Organized flame front - fire progressing } \\
\text { in organized manner } \\
\text { - Occasional candling may be observed along the } \\
\text { perimeter and/or within the fire } \\
\text { - Moderate rate of spread }\end{array}$ \\
\hline & 4 & $\begin{array}{l}\text { Highly vigorous surface fire with torch- } \\
\text { ing, or passive crown fire }\end{array}$ & $\begin{array}{l}\text { - Grey to black smoke } \\
\text { - Organized surface flame front } \\
\text { - Moderate to fast rate of spread on the ground } \\
\text { - Short aerial bursts through the forest canopy } \\
\text { - Short-range spotting }\end{array}$ \\
\hline & 5 & $\begin{array}{l}\text { Extremely vigorous surface fire } \\
\text { or active crown fire }\end{array}$ & $\begin{array}{l}\text { - Black to copper smoke } \\
\text { - Organized crown fire front } \\
\text { - Moderate to long-range spotting and independent } \\
\text { spot fire growth }\end{array}$ \\
\hline & 6 & $\begin{array}{l}\text { A blow up or conflagration; } \\
\text { extreme and aggressive fire behavior }\end{array}$ & $\begin{array}{l}\text { - Organized crown fire front } \\
\text { - Long-range spotting and independent spot } \\
\text { fire growth } \\
\text { - Possible fireballs and whirls } \\
\text { - Violent fire behavior probable } \\
\text { - A dominant smoke column may develop which } \\
\text { influences fire behavior }\end{array}$ \\
\hline
\end{tabular}

age tanks subject to thermal loading has been thoroughly investigated in Liu (2011) and Mansour (2012). A review of oil storage steel tanks under different types of loads, including thermal loading, can also be found in Godoy (2016). Exposed to external fires, empty or partially filled storage tanks may receive temperatures up to 5 times higher than completely filled tanks, and thus are more susceptible to buckling. For partially filled tanks, there is even a jump between the temperature below and above the liquid level (Liu, 2011).
In addition to the possibility of buckling, which endangers the integrity of storage tanks, petroleum products may ignite spontaneously at their auto-ignition temperatures in normal atmosphere without even direct impingement of wildfire flames or airborne embers. The auto-ignition temperature of most petroleum products is between 200 and $250{ }^{\circ} \mathrm{C}$, well below the temperature required for buckling of steel storage tanks and easily reachable for storage tanks exposed to the radiant heat of wildfires. For intact atmospheric storage tanks, the auto-ignition of flammable contents would most proba- 


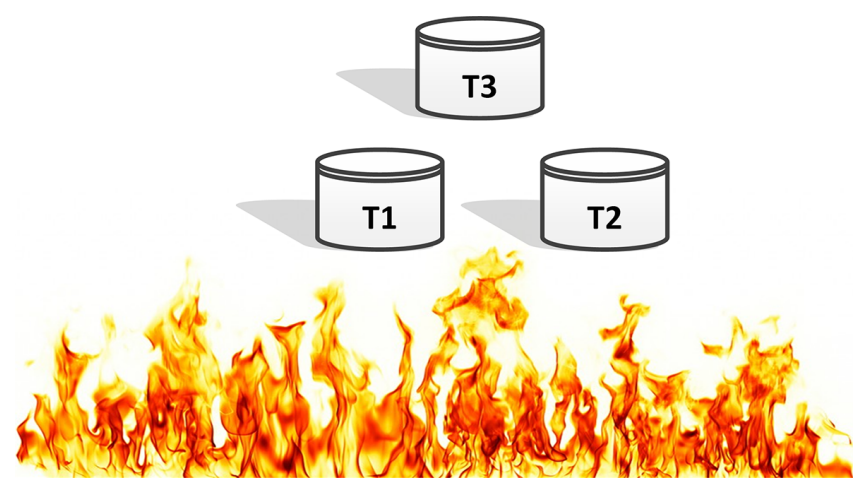

Figure 10. An exemplary storage plant exposed to the heat of wildfire.

bly lead to tank fires, while for damaged storage tanks with spilled fuel in the catch basins, it would lead to pool fires.

For pressurized tanks such as $\mathrm{LPG}^{5}$ tanks, on the other hand, a BLEVE (boiling liquid expanding vapor explosion) is the most likely scenario. A BLEVE occurs when the increase in the internal vapor pressure of the tank exposed to an external fire grows beyond the strength of the already weakened tank wall, leading to the formation of a tear. If the tear spreads to the entire length of the tank, a BLEVE occurs, followed by a fireball; otherwise, a jet fire would be expected (Birk and Cunningham, 1994). In order to prevent an increase in the internal overpressure, pressurized tanks are usually equipped with pressure relief valves or fusible plugs, which are nevertheless likely to be damaged and fail to operate (CSB, 2008). Furthermore, to prevent a BLEVE, the American Petroleum Institute (API) has identified a maximum heat radiation intensity of $22 \mathrm{~kW} \mathrm{~m}^{-12}$ to which LPG tanks should be exposed (API, 1996). Performance and safety of LPG tanks exposed to radiant heat of wildfires have been investigated by Heymes et al. (2013).

Despite the fact that the risk of radiant heat seems easier to quantify (than the risk of airborne embers) based on current techniques and available databases, it is missing in the available directives and guidelines. For instance, FireSmart ${ }^{\circledR}$, a Canadian field guide for protecting oil and gas facilities against wildfires, identifies a rule-of-thumb minimum safety distance of $3 \mathrm{~m}$ for propane tanks (pressurized tank) from forest vegetation (FireSmart, 2012). However, Heymes et al. (2013) showed that even a small fire of $2 \mathrm{~m}$ high and $5 \mathrm{~m}$ wide is able to increase the internal pressure of LPG tanks and eventually lead to a BLEVE and subsequent fireball.

To quantify the impact of a wildfire on an oil and gas facilities, the damage probabilities of the process vessels exposed to the wildfire's radiant heat (i.e., the primary vessels) as well as the damage probability of neighboring vessels exposed to

\footnotetext{
${ }^{5}$ Liquefied petroleum gas (LPG), mostly consisting of propane and butane, is a flammable substance used as fuel in heating, cooking, and vehicles.
}

the heat radiation of fires at the primary vessels need to be assessed. In this regard, dose-response relationships which associate the damage probability of process vessels with the intensity of received heat radiation can be used.

For instance, Cozzani et al. (2005) developed simplified probit functions to correlate the time to failure (ttf) of vessels to their size and the intensity of received heat (a minimum required value of $15 \mathrm{~kW} \mathrm{~m}^{-2}$ for atmospheric vessels and $50 \mathrm{~kW} \mathrm{~m}^{-2}$ for pressurized vessels). Equations (9)-(11) can be used to assess the damage probability of atmospheric process vessels, including the storage tanks:

$$
\begin{aligned}
& \ln (\mathrm{ttf})=-1.13 \ln \left(Q_{x}\right)-2.67 \times 10^{-5} V+9.9 \\
& Y=12.54-1.85 \ln (\mathrm{ttf}) \\
& P=\phi(Y-5),
\end{aligned}
$$

where $\operatorname{ttf}(\mathrm{s})$ is the time to failure of the exposed vessel (due to the wildfire's heat or a primary tank fire's heat); $Q_{X}$ $\left(\mathrm{kW} \mathrm{m}^{-2}\right)$ is the received heat radiation by the vessel, calculated using Eq. (8); $V\left(\mathrm{~m}^{3}\right)$ is the volume of the vessel; $Y$ is the probit value; $P$ is the damage probability of the vessel; $\phi($.$) is the cumulative standard normal distribution. For the$ sake of exemplification, consider the hypothetical tank farm in Fig. 10, where atmospheric storage tanks T1 and T2 are exposed to the wildfire's radiant heat of greater than $15 \mathrm{~kW} \mathrm{~m}^{-2}$ and may catch fire. Tank T3 is too far to be damaged directly by the wildfire's heat radiation but may be damaged via a domino effect given wildfire-induced fires at $\mathrm{T} 1$ or $\mathrm{T} 2$.

Given the characteristics of the wildfire, the location of the tank farm (e.g., using Fig. 4b) and the distance of the storage tanks from the head fire, the amount of radiant heat received by $\mathrm{T} 1$ and $\mathrm{T} 2$ can be calculated using Eqs. (7) and (8); accordingly, the conditional damage probabilities of the tanks given the wildfire, i.e., $P(\mathrm{~T} 1 \mid \mathrm{wf})$ and $P(\mathrm{~T} 2 \mid \mathrm{wf})$, can be estimated using the probit functions given in Eqs. (9-11). Given that the wildfire would ignite tank fires at either T1 or $\mathrm{T} 2$, three mutually exclusive domino effect scenarios can be envisaged in which T3 would be damaged and catch fire from either T1 or T2 (Fig. 11).

As a result, $P(\mathrm{~T} 3 \mid \mathrm{wf})$ can roughly be estimated as the aggregation of the three domino effect scenarios as $P(\mathrm{~T} 3 \mid \mathrm{wf})=P(\mathrm{~T} 3 \mid \mathrm{wf})_{a}+P(\mathrm{~T} 3 \mid \mathrm{wf})_{b}+P(\mathrm{~T} 3 \mid \mathrm{wf})_{c}$, where

- according to Fig. 11a,

$$
\begin{aligned}
P(\mathrm{~T} 3 \mid \mathrm{wf})_{a} & =P(\mathrm{~T} 1 \mid \mathrm{wf}) \cdot(1-P(\mathrm{~T} 2 \mid \mathrm{wf})) \cdot\{P(\mathrm{~T} 3 \mid \mathrm{T} 1) \\
& \cup\{P(\mathrm{~T} 2 \mid \mathrm{T} 1) \cdot P(\mathrm{~T} 3 \mid \mathrm{T} 2)\}\} ;
\end{aligned}
$$

- according to Fig. 11b,

$$
\begin{gathered}
P(\mathrm{~T} 3 \mid \mathrm{wf})_{b}=(1-P(\mathrm{~T} 1 \mid \mathrm{wf})) \cdot P(\mathrm{~T} 2 \mid \mathrm{wf}) \cdot\{\{P(\mathrm{~T} 1 \mid \mathrm{T} 2) \\
\cdot P(\mathrm{~T} 3 \mid \mathrm{T} 1)\} \cup P(\mathrm{~T} 3 \mid \mathrm{T} 2)\} ;
\end{gathered}
$$

- according to Fig. 11c,

$$
\begin{aligned}
P(\mathrm{~T} 3 \mid \mathrm{wf})_{c} & =P(\mathrm{~T} 1 \mid \mathrm{wf}) \cdot P(\mathrm{~T} 2 \mid \mathrm{wf}) \\
\cdot & \{P(\mathrm{~T} 3 \mid \mathrm{T} 1) \cup P(\mathrm{~T} 3 \mid \mathrm{T} 2)\} .
\end{aligned}
$$




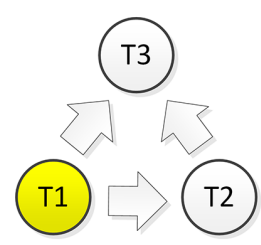

(a)

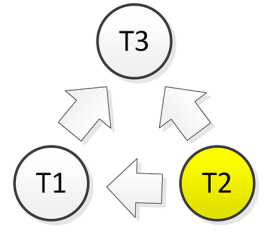

(b)

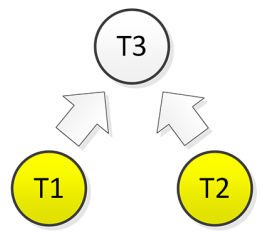

(c)
Figure 11. Wildfire-induced domino effect scenarios. (a) T1 catches fire as it is exposed to the heat of the wildfire, and triggers secondary fires at $\mathrm{T} 2$ and $\mathrm{T} 3$ via a domino effect. (b) T2 catches fire as it is exposed to the heat of the wildfire, and triggers secondary fires at T1 and T3 via a domino effect. (c) Both T1 and T2 catch fire as they are exposed to the heat of the wildfire, and trigger a secondary fire at $\mathrm{T} 3$ via a domino effect. Tanks directly impacted by the wildfire have been highlighted yellow.

Similar to $P(\mathrm{~T} 1 \mid \mathrm{wf})$ and $P(\mathrm{~T} 2 \mid \mathrm{wf})$, the conditional probabilities $P(\mathrm{~T} 1 \mid \mathrm{T} 2), P(\mathrm{~T} 2 \mid \mathrm{T} 1), P(\mathrm{~T} 3 \mid \mathrm{T} 1)$ and $P(\mathrm{~T} 3 \mid \mathrm{T} 2)$ can be estimated using probit functions in Eqs. (9)-(11) based on the amount of heat radiation a secondary tank receives from fire at a primary tank. Having the conditional damage probabilities of the storage tanks (conditioned on the occurrence of a wildfire of given characteristics), the marginal damage probabilities, e.g., for T3, can be calculated as $P(\mathrm{~T} 3)=$ $P_{\mathrm{w}} \cdot P(\mathrm{~T} 3 \mid \mathrm{wf})=P_{\mathrm{I}} \cdot P_{\mathrm{B}} \cdot P(\mathrm{~T} 3 \mid \mathrm{wf})$.

For large oil and gas facilities with many process vessels of different types and dimensions, for which complicated interaction among the process vessels would not allow a manual calculation of damage probabilities, more sophisticated techniques such as a Bayesian network (Khakzad, 2015) can be employed.

\section{Conclusions}

The present study has been inspired by recent massive wildfires in the province of Alberta, Canada, jeopardizing the operation and safety of oil sands facilities as a key contributing factor to the nation's economy. Despite the extensive oil sands operations in Canadian wildlands and an everincreasing risk of wildfires, mainly due to global warming, quantitative methodologies for assessing and managing the risk of wildfires in the context of natechs (i.e., technological accidents triggered by natural disasters) are lacking.

In the present study, we made an attempt to develop a risk assessment methodology for wildfire-prone oil sands facilities by integrating the Canadian online wildfire information system and available quantitative risk assessment (QRA) techniques. Since the wildfire information system is updated on a daily basis, providing forecasts for the same day and the next day, the developed methodology can help facilities owners and safety managers predict the risk of wildfires at least a day ahead of time and thus devise appropriate protection and mitigation measures.
In most wildland oil and gas facilities, the separation distances (buffer zones) between oil facilities and forest vegetation are usually determined based on approximate analyses (e.g., in Canada, it is based on FireSmart ${ }^{\circledR}$ guidelines). As such, similar methodologies to the one proposed in the present study can be developed, not only for the risk-based identification of more dependable buffer zones, but also for the design of oil facilities so as to increase their robustness against wildfire-induced damage and potential domino effect scenarios.

Data availability. No data sets were used in this article. 


\section{Appendix A: Nomenclature}

$\begin{array}{ll}\text { API: } & \text { American Petroleum Institute } \\ \text { BUI: } & \text { Buildup Index } \\ \text { D: } & \text { flame depth } \\ \text { DC: } & \text { Drought Code } \\ \text { DMC: } & \text { Duff Moisture Code } \\ \text { FBP: } & \text { Fire Behavior Prediction } \\ \text { FFMC: } & \text { Fine Fuel Moisture Code } \\ \text { FWI: } & \text { Fire Weather Index } \\ F_{\text {view }}: & \text { view factor } \\ h: & \text { flame height } \\ H: & \text { fuel's low heat of combustion } \\ \text { HFI: } & \text { head fire intensity } \\ \text { ISI: } & \text { Initial Spread Index } \\ L: & \text { flame length } \\ P(.): & \text { marginal damage probability of target vessel } \\ P(. \mid \text { wf): } & \text { conditional damage probability of target vessel given a wildfire } \\ P_{\text {arr }}: & \text { probability of a smoldering fire escalating to a flaming fire } \\ P_{\mathrm{B}}: & \text { burn probability } \\ P_{\text {ign }}: & \text { probability of ignition given a long-continuing current } \\ P_{\mathrm{I}}: & \text { probability of ignition } \\ P_{\mathrm{LCC}}: & \text { probability of a long-continuing current } \\ P_{\mathrm{sur}}: & \text { probability that a smoldering ignition survives } \\ P_{\mathrm{w}}: & \text { probability of wildfire } \\ Q: & \text { reaction intensity } \\ Q_{x}: & \text { heat radiation at the distance of } x \\ r: & \text { fire's rate of spread in the direction of the fire head } \\ \text { ROS: } & \text { rate of spread } \\ \text { ttf: } & \text { time to failure of target vessel } \\ V: & \text { volume of target vessel } \\ w: & \text { fuel's combustion rate in the flaming zone } \\ \text { WIPP: } & \text { wildfire ignition probability predictor } \\ x: & \text { horizontal distance from the flame's center } \\ Y: & \text { probit value } \\ \tau_{\mathrm{a}}: & \text { atmospheric transmissivity } \\ \phi: & \text { cumulative standard normal distribution } \\ & \end{array}$


Appendix B: Identification of view factors in the Solid Flame Model

$F_{\text {view }}$ can be calculated as a function of vertical $F_{\mathrm{v}}$ and horizontal $F_{\mathrm{h}}$ view factors as (Assael and Kakosimos, 2010)

$F_{\text {view }}=\sqrt{F_{\mathrm{v}}^{2}+F_{\mathrm{h}}^{2}}$

where

$$
\begin{aligned}
& \pi F_{\mathrm{v}}=-E \tan ^{-1} \varnothing \\
& +E\left[\frac{\alpha^{2}+(\beta+1)^{2}-2 \beta(1+\alpha \sin \theta)}{\mathrm{AB}}\right] \tan ^{-1}\left(\frac{A \varnothing}{B}\right) \\
& +\frac{\cos \theta}{C}\left[\tan ^{-1}\left(\frac{\alpha \beta-F^{2} \sin \theta}{\mathrm{FC}}\right)+\tan ^{-1}\left(\frac{F \sin \theta}{C}\right)\right] \\
& \pi F_{\mathrm{h}}=\tan ^{-1}\left(\frac{1}{\varnothing}\right) \\
& +\frac{\sin \theta}{C}\left[\tan ^{-1}\left(\frac{\alpha \beta-F^{2} \sin \theta}{F C}\right)+\tan ^{-1}\left(\frac{F \sin \theta}{C}\right)\right] \\
& -\left[\frac{\alpha^{2}+(\beta+1)^{2}-2(\beta+1+\alpha \beta \sin \theta)}{A B}\right] \tan ^{-1}\left(\frac{A \varnothing}{B}\right) \\
& \alpha=\frac{L}{R} \\
& \beta=\frac{X}{R} \\
& A=\sqrt{\alpha^{2}+(\beta+1)^{2}-2 \alpha(\beta+1) \sin \theta} \\
& B=\sqrt{\alpha^{2}+(\beta-1)^{2}-2 \alpha(\beta-1) \sin \theta} \\
& C=\sqrt{1+\left(\beta^{2}-1\right) \cos ^{2} \theta} \\
& \varnothing=\sqrt{(\beta-1) /(\beta+1)} \\
& E=\frac{\alpha \cos \theta}{\beta-\alpha \sin \theta} \\
& F=\sqrt{\beta^{2}-1} \text {. }
\end{aligned}
$$

The angle of tilt, $\theta$, can be calculated as a function of wind speed $u_{\mathrm{w}}$ as (Pritchard and Binding, 1992)

$\frac{\tan \theta}{\cos \theta}=0.666 F r^{0.333} \operatorname{Re}^{0.117}$,

where $F r$ is the Froud number $F r=\frac{u_{\mathrm{w}}^{2}}{g \varnothing}$, and $R e$ is the Reynolds number $R e=\frac{u_{\mathrm{w}} \rho_{\mathrm{a}} \varnothing}{\eta_{\mathrm{a}}}$, both non-dimensional numbers. $\rho_{\mathrm{a}}$ and $\eta_{\mathrm{a}}$ are, respectively, the density $\left(\sim 1.21 \mathrm{~kg} \mathrm{~m}^{-3}\right)$ and viscosity ( $\sim 16.7 \mu \mathrm{Pa} \mathrm{s})$ of air; $g$ is gravitational acceleration $\left(\sim 9.81 \mathrm{~m} \mathrm{~s}^{-2}\right)$.

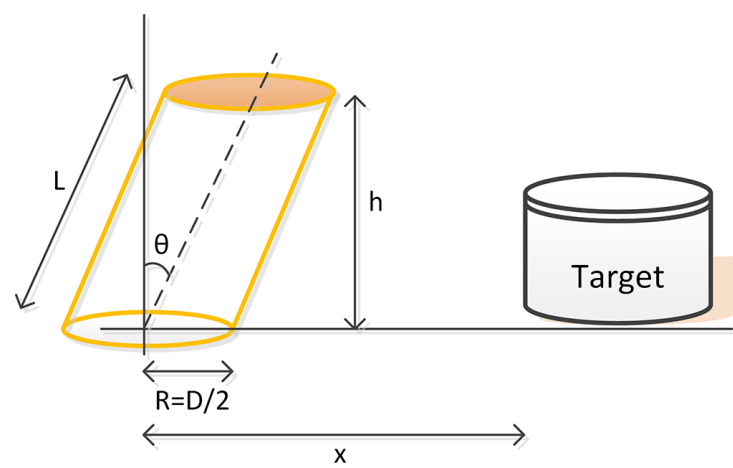

Figure B1. Flame as a tilted cylinder. 
Competing interests. The author declares that there is no conflict of interest.

Edited by: Rosa Lasaponara

Reviewed by: two anonymous referees

\section{References}

Alexander, M. E.: Calculating and interpreting forest fire intensities, Can. J. Botany, 60, 349-357, 1982.

Alexander, M. E. and Cruz, M. G.: Interdependencies between flame length and fireline intensity in predicting crown fire initiation and crown scorch height, Int. J. Wildland Fire, 21, 95-113, 2012.

American Petroleum Institute (API): Fire-protection considerations for the design and operation of liquefied petroleum gas (LPG) storage facilities, Publication 2510A, 2nd edition, American Petroleum Institute, Washington DC, US, 1996.

Andrews, P. L.: Current status and future needs of the BehavePlus Fire Modeling System, Int. J. Wildland Fire, 23, 21-33, 2013.

Anderson, K. R.: A model to predict lightning-caused fire occurrences, Int. J. Wildland Fire, 11, 174-182, 2002.

Assael, M. J. and Kakosimos, K. E. (Eds.): Fires, explosions, and toxic gas dispersions: Effects calculation and risk analysis, 1st Edition, CRC Press, Taylor \& Francis Group, Boca Raton, FL, 2010

Birk, A. M. and Cunnigham, M. H.: The boiling liquid expanding vapor cloud explosion, J. Loss Prevent. Proc., 7, 474-480, 1994.

Butler, B. W. and Cohen, J. D.: Field verification of a firefighter safety zone model, the 2000 International Wildfire Safety Summit, Edmonton, Alberta, 10-12 October 2000, 54-61, 2000.

Byram, G. M.: Combustion of forest fuels, in: Forest Fire: Control and Use, edited by: Davis, K. P., McGraw Hill, New York, 61-89, 1959.

Chemical Safety Board (CSB): LPG fire at Valerio-McKee Refinery, Report No. 2007-05-I-TX, available at: https://www.csb. gov/valero-refinery-propane-fire/ (last access: 11 October 2018), 2008.

Cheney, N. P.: Quantifying bushfires, Math. Comput. Model., 13, 9-15, 1990.

Cheney, N. P., Gould, J. S., and Catchpole, W. R.: Prediction of fire spread in grasslands, Int. J. Wildland Fire, 8, 1-13, 1998.

Chuvieco, E., Aguado, I., and Dimitrakopoulos, A. P.: Conversion of fuel moisture content values to ignition potential for integrated fire danger assessment, Can. J. Forest Res., 34, 2284-2293, 2004.

Cozzani, V., Gubinelli, G., Antonioni, G., Spadoni, G., and Zanelli, S.: The assessment of risk caused by domino effect in quantitative area risk analysis, J. Hazard. Mater., A127, 14-30, 2005.

European Joint Research Centre, available at: https://ec.europa.eu/ jrc/en/news/europe-be-hit-hard-climate-related-disasters-future (last access: 11 October 2018), 2017.

Finney, M. A.: FARSITE: Fire Area Simulator - model development and evaluation, Res. Pap. RMRS-RP-4, Department of Agriculture, Forest Service, Rocky Mountain Research Station, Fort Collins, CO, U.S., 47 pp., 1998.

Finney, M. A.: Fire growth using minimum travel time methods, Can. J. Forest Res., 32, 1420-1424, 2002.
Finney, M. A.: An overview of FlamMap fire modeling capabilities, in: Fuels management-how to measure success, edited by: Andrews, P. L. and Butler, B. W., Proc. RMRS-P-41, Department of Agriculture, Forest Service, Rocky Mountain Research Station, Fort Collins, CO, U.S., 213-220, 2006.

Finney, M. A., Grenfell, I. C., McHugh, C. W., Seli, R. C., Tretheway, D., Stratton, R. D., and Britton, S.: A method for ensemble wildland fire simulation, Environ. Model. Assess., 16, 153-167, 2011a.

Finney, M. A., McHugh, C. W., Grenfell, I. C., Riley, K. L., and Short, K. C.: A simulation of probabilistic wildfire risk components for the continental United States, Stoch. Env. Res. Risk A., 25, 973-1000, 2011b.

FireSmart ${ }^{\circledR}$ : Canadian Guidebook for the Oil and Gas Industry, Alberta, Canada, available at: http://wildfire.alberta.ca/firesmart/ documents/FireSmart-Guidebook-OilAndGasIndustry-2008.pdf (last access: 11 October 2018), 2012.

Flannigan, M. D., Wotton, B. M., Marshall, G. A., de Groot, W. J., Johnston, J., Jurko, N., and Cantin, A. S.: Fuel moisture sensitivity to temperature and precipitation: climate change implications, Climatic Change, 134, 59-71, 2016.

Forestry Canada Fire Danger Group: Development and structure of the Canadian Forest Fire Behavior Prediction System, For. Can. Ottawa, ON. Inf. Rep. ST-X-3, Forestry Canada, Ottawa, ON, 1992.

Global News: Fort McMurray wildfire: Oilsands work camp destroyed as flames threaten other sites, 17 May 2016, available at: https://globalnews.ca/news/2706177/fort-mcmurray-wildfireseveral-homes-damaged-in-explosion-in-dickinsfield-fire-inthickwood/ (last access: 11 October 2018), 2016a.

Global News: Why experts say Alberta oilsands sites are considered resilient to wildfires, 17 May 2016, available at: https://globalnews.ca/news/2707147/why-experts-sayalberta-oilsands-sites-are-considered-resilient-to-wildfires/ (last accessed 11 October 2018), 2016b.

Godoy, L.: Buckling of vertical oil storage steel tanks: Review of static buckling studies, Thin Wall. Struct., 103, 1-21, 2016.

Hartford, R. A.: Smoldering combustion limits in peat as influenced by moisture, mineral content, and organic bulk density, the 10th Conference on Fire and Forest Meteorology, Ottawa, ON, Canada, 17-21 April, 282-286, 1989.

Heymes, F., Aprin, L., Forestier, S., Slangen, P., Jarry, J. B., François, H., and Dusserre, G.: Impact of a distant wildland fire on an LPG tank, Fire Safety J., 61, 100-107, 2013.

Jurdao, S., Chuvieco, E., Jorge, M., and Arevalillo, J. M.: Modelling fire ignition probability from satellite estimates of live fuel moisture content, Fire Ecol., 8, 77-97, 2012.

Khakzad, N.: Application of dynamic Bayesian network to risk analysis of domino effects in chemical infrastructures, Reliab. Eng. Syst. Safe., 138, 263-272, 2015.

Khakzad, N., Dadashzadeh, M., and Reniers, G.: Quantitative assessment of wildfire risk in oil facilities, J. Environ. Manage., 223, 433-443, 2018.

Krausmann, E. and Baranzini, D.: Natech risk reduction in the European Union, J. Risk Res., 15, 1027-1047, 2012.

Larjavaara, M., Kuuluvainen, T., Tanskanen, H., and Venäläinen, A.: Variation in forest fire ignition probability in Finland, Silva Fenn., 38, 253-266, 2004. 
Latham, D. J. and Schlieter, J. A.: Ignition probabilities of wildland fuels based on simulated lightning discharges, USDA For. Serv. Ogden, UT. Res. Pap. INT-411, United states Department of Agriculture (USDA), Ogden, Utah, 1989.

Lawson, B. D., Armitage, O. B., and Dalrymple, G. N.: Ignition probabilities for simulated people-caused fires in B.C.'s lodge pole pine and white spruce-subalpine fire forests, 12th Conference on Fire and Forest Meteorology, Beltsville, MD, U.S., 2628 October 1993, 493-505, 1994.

Liu, Y.: Thermal buckling of metal oil tanks subject to an adjacent fire, PhD Thesis, University of Edinburgh, Scotland, 2011.

Maclean's: The Fort McMurray wildfire has hit the oil sands hard, 6 May 2016, available at: http://www.macleans.ca/economy/thefort-mcmurray-wildfire-has-hit-the-oil-sands-hard/ (last access: 11 October 2018), 2016a.

Maclean's: Could the oil sands catch fire?, 4 May 2016, available at: http://www.macleans.ca/news/canada/could-the-oilsands-catch-fire/ (last access: 11 October 2018), 2016 b.

Mansour, K.: Fires in large atmospheric storage tanks and their effect on adjacent tanks, PhD Thesis, Loughborough University, UK, 2012.

Mining.Com: Wildfire spreads closer to Canada's oil sands: hundreds evacuated, 28 May 2015, available at: http://www.mining.com/wildfire-spreads-closer-to-canadasoil-sands-hundreds-evacuated/ (last access: 11 October 2018), 2015.

Mudan, K. S.: Geometric view factors for thermal radiation hazard assessment, Fire Safety J., 12, 89-96, 1987.

National Geographic, Learn more about wildfires, available at: https://www.nationalgeographic.com/environment/ natural-disasters/wildfires/, last access: 27 July 2018.

Natural Resources Canada: Canadian Wildland Fire Information System, available at: http://cwfis.cfs.nrcan.gc.ca/background/ summary/fwi, last access: 11 October 2018.

Papadopoulos, G. D. and Pavlidou, F. N.: A Comparative Review on Wildfire Simulators, IEEE Syst. J., 5, 233-243, 2011.

Pastor, E., Zarate, L., Planas, E., and Arnaldos, J.: Mathematical models and calculation systems for the study of wildland fire behavior, Prog. Energ. Combust., 29, 139-153, 2003.

Preisler, H. K., Brillinger, D. R., Burgan, R. E., and Benoit, J. W.: Probability based models for estimation of wildfire risk, Int. J. Wildland Fire, 13, 133-142, 2004.
Romps, D. M., Seeley, J. T., Vollaro, D., and Molinari, J.: Projected increase in lightning strikes in the United States due to global warming, Science, 346, 851-854, 2014.

Rothermel, R. C.: A mathematical model for predicting fire spread in wildland fuels, Res. Pap. INT-115, U.S. Department of Agriculture, Forest Service, Intermountain Forest and Range Experiment Station, Ogden, UT, 40 pp., 1972.

Rothermel, R. C.: Predicting behavior and size of crown fires in the Northern Rocky Mountains. Res. Pap. INT-438, U.S. Department of Agriculture, Forest Service, Intermountain Forest and Range Experiment Station, Ogden, UT, 46 pp., 1991.

Scott, J., Helmbrecht, D., Thompson, M. P., Calkin, D. E., and Marcille, K.: Probabilistic assessment of wildfire hazard and municipal watershed exposure, Nat. Hazards, 64, 707-728, 2012.

Scott, J., Thompson, M. P., and Calkin, D. E.: A wildfire risk assessment framework for land and resource management, General Technical Report RMRS-GTR-315, U.S. Department of Agriculture, Forest Service, Rocky Mountain Research Station, 83 pp., available at: https://www.nrs.fs.fed.us/pubs/44723 (last access: 11 October 2018), 2013.

Seveso Directive III, Directive 2012/18/EU of the European Parliament and of the Council of 4 July 2012 on the control of major-accident hazards involving dangerous substances, amending and subsequently repealing Council Directive 96/82/EC, Official Journal of the European Communities, No L 197, 1-37, 2012.

Tymstra, C., Bryce, R. W., Wotton, B. M., Taylor, S. W., and Armitage, O. B.: Development and Structure of Prometheus: the Canadian Wildland Fire Growth Simulation Model, INFORMATION REPORT NOR-X-417, Natural Resources Canada, Canadian Forest Service, Northern Forestry Centre, Victoria, BC, Canada, 2010.

Van Wagner, C. E.: Conditions for the start and spread of crown fire, Can. J. Forest Res., 7, 23-34, 1977.

Wilensky, U.: NetLogo Fire model, Center for Connected Learning and Computer-Based Modeling, Northwestern University, Evanston, IL, available at: http://ccl.northwestern.edu/netlogo/ models/Fire (last access: 11 October 2018), 1997. 